\title{
Correction to: Galcanezumab: A Review in the Prevention of Migraine and Treatment of Episodic Cluster Headache
}

Lesley J. Scott ${ }^{1}$

Published online: 25 July 2020

C) Springer Nature Switzerland AG 2020

Correction to: Drugs (2020) 80:893-904

https://doi.org/10.1007/s40265-020-01329-5

Correction to reviewer name:

Page 893. The name of the first reviewer which previously read:

J. R. Crouch Jr,

Should read.

J. R. Couch Jr,

The original article can be found online at https://doi.org/10.1007/ s40265-020-01329-5.

Lesley J. Scott

demail@springer.com

1 Springer Nature, Private Bag 65901, Mairangi Bay, Auckland 0754, New Zealand 